\title{
Temporal and spatial variability of environments drive the patterns of species richness along latitudinal, elevational, and depth gradients
}

\author{
Nikolay Kolomiytsev and Nadezhda Poddubnaya \\ Department of Biology, Cherepovets State University, 5 Lunacharsky Ave., \\ Cherepovets, Vologda Region, 162600, Russian Federation \\ Address correspondence and requests for materials to Nadezhda Poddubnaya, \\ poddoubnaia@mail.ru
}

\begin{abstract}
This paper seeks to shed light on the primary causes of the latitudinal cline in species diversity, the asymmetry in species richness between the northern and southern hemispheres, and various patterns of species richness along mountain and continental slopes, which are at present of central interest in ecology. To that end, we restate, further develop and unify Janzen's ideas about the higher fidelity of tropical organisms to their habitats; the notions of Sanders on temporal and spatial variations of environment and their impact on the breadth of species adaptations; the hypothesis of latitude-niche breadth and niche overlap; the theories of climatic stability, competitive exclusion and competitive divergence with the incorporation of some elements of the gradient model of diversification. We argue that during adaptation to a wide range of the same environmental factors in time, the high latitude species also become adapted to a wide range of those factors in space. As a result, they form not only very wide, but also widely overlapping ecological niches. This eventually leads to the competitive extinction of many species and a general impoverishment of biota. In contrast, relatively stable environments allow species to move more and more towards specialization with a simultaneous narrowing of their ecological niches that in turn leads to a reduction of niche overlap and greater species packing in communities. In tropical mountains and on the continental slope, where the environment is stable enough, the degree of its differentiation depends mainly on the steepness of slope. And since the steepest slopes tend to be located at intermediate elevations and intermediate bathyal depths, it is there that there are conditions for the highest specialization. These ideas can provide a framework for new approaches to biodiversity conservation of different regions.
\end{abstract}

Keywords: competitive divergence, competitive extinction, environmental variability, niche overlap, specialization, species packing, species richness

\section{Introduction}

The overall increase in species richness from high latitude to the equatorial region, which is more pronounced in the forest communities (Wallace, 1878; Dobzhansky, 1950) and shallow coastal and shelf areas (Roy, Jablonski, Valentine, and Rosenberg, 1998), is one of the longest standing, most well-known and highly general spatial patterns of ecology. This increase, however, is not always monotonic (Roy, Jablonski, Valentine, and Rosenberg, 1998; Crame, 2000) and is often seriously disturbed by various factors. On land, among the most important of such factors are water deficit and extreme temperatures (O’Brien, 1993; Buckley and Jetz, 2007; Smith, de Oca, Reeder, and Wiens, 2007); in oceans-dissolved oxygen shortage (Levin, 2003), oceanic currents (Owen, 1981 and references therein; Veron, 1995), upwelling processes (Owen, 1981 and references therein; Macpherson, 2002) and large river outflow (Veron, 1995; Macpherson, 2002). In 
addition, the latitudinal change in species diversity may be different for different taxa (Macpherson, 2002; Powney et al., 2010), and some rare taxa. For example, true seals (Wilson and Reeder, 2005), penguins (Williams, 1995), auks (Gaston and Jones, 1998), sandpipers (Johnsgard, 1981; Colwell, 2010), lampropeltinines snakes (Pyron and Burbrink, 2009) and freshwater amphipods (Väinölä et al., 2008), due to the peculiarities of their natural history and biology, show a directly opposite tendency. Some groups of marine zooplankton (Boltovskoy, Gibbons, Hutchings, and Binet, 1999 and references therein; Boltovskoy, D'Hondt, and Prell, 1999), parasitic wasps of the family Ichneumonidae (Janzen, 1981), burying beetles (Peck and Kaulbars, 1987), eared seals (Wilson and Reeder, 2005) and some others reach their peak of species diversity in middle latitudes. Nevertheless, a latitudinal cline in species richness is detected in all main habitats, including freshwaters (France, 1992; Pringle, 2000) and the open-ocean pelagic zone (Angel, 1993; Macpherson, 2002), and is observed both in plants and exothermic and endothermic animals (Rosenzweig, 1995). It has been established even in marine bacterial plankton (Fuhrman et al., 2008) and within some widespread families and genera (Slansky, 1972; Scriber, 1973; Dodge and Marshall, 1994). Furthermore, in the case of birds it has been shown that not only species diversity, but also the number of subspecies within species and phenotypic differentiation of populations are greater at lower latitudes (Martin and Tewksbury, 2008).

By now, an extensive body of literature has been devoted to the study and description of latitudinal species diversity patterns, and many competing or complementary explanatory hypotheses have been proposed (see, e.g., Pianka, 1966; MacArthur, 1972; Pielou, 1979; Huston, 1994; Wright, 2002; Willig, Kaufman, and Stevens, 2003; Evans et al., 2005; Mittelbach et al., 2007; Bukvareva and Aleshchenko, 2013). Gaston (2000) gracefully presented more than two dozen hypotheses in one work and outlined the questions for the solution of this question. Willig, Kaufman, and Stevens (2003) provided a classification of the over 30 hypotheses advanced to account for the latitudinal gradient: abiotic-biotic, ambient energy, environmental predictability, seasonality, environmental stability, evolutionary rates, extinction rate and origination rate, evolutionary speed, geographic area, geometric constraints, interspecific interaction, competition, niche width, population growth rate and population size, productivity, Rapoport's rule, spatial heterogeneity, time, etc., and a forward-looking synthesis and list of fertile areas for future research. Lomolimo, Riddle, Whittaker, and Brown (2010) identified three blocks of hypotheses for the Geography of Diversity: ultimate drivers - primary abiotic factors, ecological feedback (intensifies, obfuscates, or otherwise modifies the latitudinal gradient), and null models, and he named
28 hypotheses. However, the definitive solution to this problem remains elusive. Furthermore, at the end of the twentieth - the beginning of the twenty-first century, the rather enigmatic problem of hump-shaped patterns of species richness along elevation and depth gradients has been added to this problem space. Here we seek to shed light on the main factors and processes determining the patterns of species diversity. We follow Willig, Kaufman, and Stevens (2003) in discussing the hypotheses most promising for promoting ecological, biogeographical and evolutionary understanding. We do not claim this to be a comprehensive review of all the hypotheses of biodiversity formation; rather, we describe different hypotheses and the ideas around them in the framework of general theory. It seems reliable and convincing and unites the hypotheses associated with the processes of adaptation and speciation in space and time.

\section{The range of seasonal climate variability and the breadth of species niches}

At first glance, an explanation of the latitudinal diversity patterns seems rather obvious: on moving from poles to equator, the environment become more favorable for living things, first of all, in regard to such important climatic factors as solar radiation and temperature. These factors, in combination with sufficient water availability, could (in the absence of other limitations) lead to an increase in primary productivity. More productive areas can support a larger number of individuals of both plants and animals that depend on plant resources, and as a result, more species may be able to maintain viable populations. Similar views have a long history. Two centuries ago Alexander von Humboldt (1808) wrote that with the increase of invigorating heat from the poles toward the equator, organic strength and vitality also gradually increase. This explanation, with different additions and modifications, has gained wide acceptance among ecologists and biogeographers in the last several decades (see, e.g., Hutchinson, 1959; Cousins, 1989; Wright, Currie, and Maurer, 1993; Rosenzweig, 1995; Evans, Warren, and Gaston, 2005).

In many studies, a significantly positive correlation between solar energy input (estimated directly or through various proxies, such as ambient temperature, annual evapotranspiration, primary productivity, biomass) and species diversity has indeed been found (Turner, Gatehouse, and Corey, 1987; Currie, 1991; Roy, Jablonski, Valentine, and Rosenberg, 1998; Schmit, 2005; Luo et al., 2012). However, when the data used were collected from a larger number of case studies, which represented various climatic zones and ecosystems of the world as well as various spatial patterns, the shape of the relationship between productivity (or biomass) and species richness was variable and could be 
any of the following: linear positive, unimodal, multimodal, U-shaped, linear negative, or non-existent (Mittelbach et al., 2001; Gillman and Wright, 2006; Pärtel, Laanisto, and Zobel, 2007; Adler et al., 2011). So, the most productive regions, as, for example, the Pacific coast of the southern hemisphere between $10^{\circ}$ and $40^{\circ}$ S (Valdovinos, Navarette, and Marquet, 2003), may have rather low species diversity. Angel (1993) has also stated that high species richness in the open oceans tends to be associated with regions of low productivity. Thus, it appears that the ultimate cause of species abundance in nature is substantially different from that of species diversity. The amount of available energy, water, minerals, and the like directly influences the primary productivity of ecosystems and the total biomass of the organisms inhabiting a given area, which changes as a result of a change in the number of individuals of existing species (Cousins, 1989; Clarke and Gaston, 2006; Rex and Etter, 2010) rather than as a result of a change in the number of species owing to increased diversification rates (Wiens, 2007), alien introductions, or extinction of some rare species (Hutchinson, 1959) and species with higher energy demands under conditions of energy limitation (Cousins, 1989).

Many researchers (Dobzhansky, 1950; Klopfer, 1959; Janzen, 1967; Slobodkin and Sanders, 1969; MacArthur, 1972; Scriber, 1973; Pielou, 1979; Stevens, 1989) share the opinion that the major importance is not so much environmental favorability as low climate variability. Their views are that: the less stable and predictable physical environment of high and temperate latitudes prevents species from specializing - i.e., induces selection for a wider environmental niche breadth; on the contrary, the steady, much more predictable, diverse and competitive environment of low latitudes favors greater specialization and allows species to have narrow niche breadth. This statement at one time had a profound impact on researchers, but it needs some elaboration.

As pointed out by Schmalhausen (1949) and then substantiated by MacArthur and Wilson (1967) and Pianka (1970), unpredictable changes in the physical environment and the catastrophic elimination caused by them are responsible mainly for the generation of some particular features of $r$-organisms, such as a high reproduction rate, accelerated development, and a short life expectancy, but exert only minimal influence on ecological niche width. However, organisms generally are able to adapt quite easily to predictable (regular) or frequently repeated (in comparison with the length of their generation intervals) environmental changes that can cause long-term trends in natural selection. Having enough time for adaptation, living beings can show a surprising ability to gradually improve their conditions of existence in such environments, even if the environments become more hostile, or seem completely uninhabitable for any forms of life (Kolomiytsev and Poddubnaya, 2007), for example, in hypersaline lakes, hyperthermal springs, and on the coast of Antarctica. Therefore, species' environmental niche breadth is, in the first instance, determined by periodic environmental fluctuations caused by the lunar rotation around the Earth and the Earth rotations around its axis and around the sun. In the hierarchy of such oscillations, the seasonal climate variability, being the largest-scale periodic phenomenon in nature, must play a dominant role.

In order to survive and reproduce at high latitudes, any species must be well enough adapted to all variations in the environment that it meets both during the year and during its lifetime (Dobzhansky, 1950). But when temperate and high latitude species adapt to a wide range of temporal variations of environmental factors, they also become adapted to a wide variety of environments in space (Janzen, 1967; Sanders, 1968; Stevens, 1989; Ghalambor et al., 2006) - i.e., they become more generalized (Pielou, 1979; Stevens, 1989). In doing so, they not only greatly expand their climatic and physiological tolerances (Stevens, 1989; Addo-Bediako, Chown, and Gaston, 2000), and often geographic ranges, especially in the meridional direction (Rapoport, 1982; Stevens, 1989; Ruggiero, 1994; Floeter and Soares-Gomes, 1999), but they also have an opportunity to occupy practically the whole set of habitats within their ranges (Sanders, 1968; Stevens, 1989) and expand their diets (MacArthur, 1972), biocenotic relationships and range of behavioural reactions. Thus, during adaptation to a wide variety of environment in time, temperate and high latitude species expand their ecological niches as a whole, and owing to large seasonal variations in environmental parameters, the niche spaces are used by them quite evenly (Fig. 1A). The arctic willow, dwarf birch, larch, willow ptarmigan, caribou, wolverine, arctic fox, ermine and lemming are examples of such species.

In contrast, a small range of seasonal variations in the environment, which can be quite harsh, rather than 'biological stress' (Sanders, 1968, p. 252) or increased availability of favoured resources (Emlin, 1966; Evans, Warren, and Gaston, 2005) should open up possibilities for species to increase not only their fidelity to their habitats (Janzen, 1967), but also to perfect their adaptations, because specialization is assumed to enable species to utilize their resources more efficiently (MacArthur, 1955; Morse, 1971), allowing them to outcompete others (Dobzhansky, 1950; MacArthur, 1955; Scriber, 1973). In such a situation, natural selection could be expected to favor individuals that possess narrower but more perfect adaptations to the most common parameters of their environment. As a result, the species would gain maximum advantage over their competitors in the core of their ecological requirements, but inevitably would weaken their positions on the periphery of their niches. In other 


\section{A}
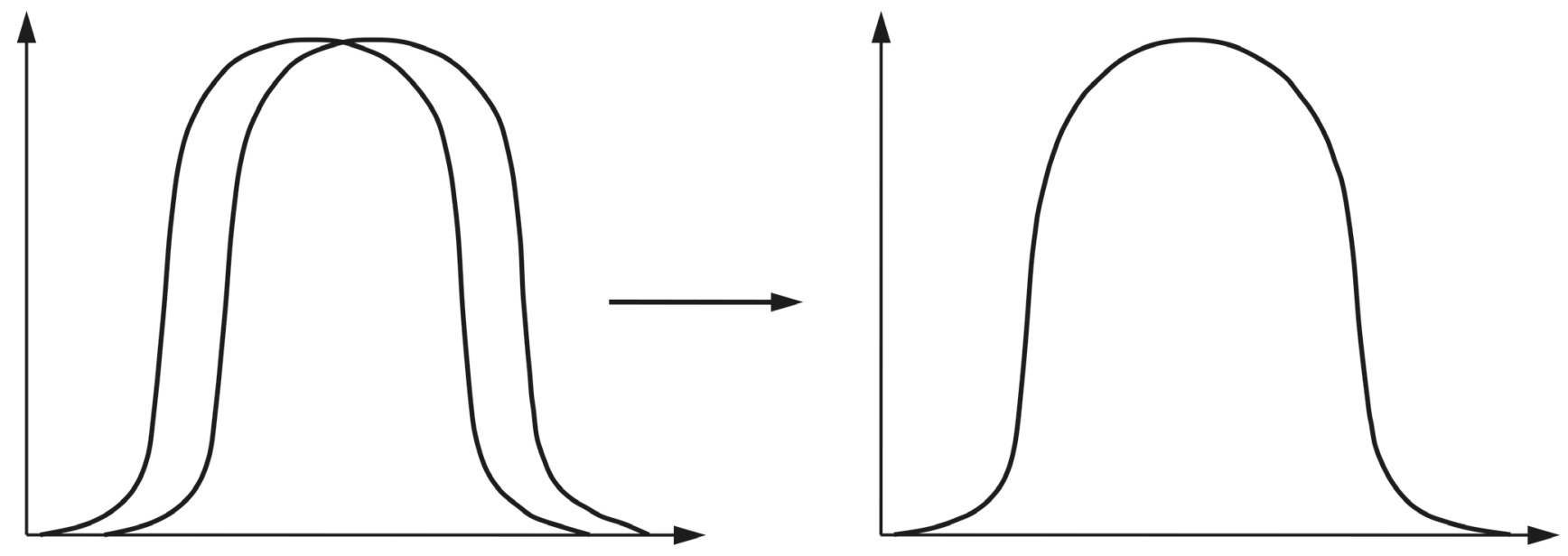

B
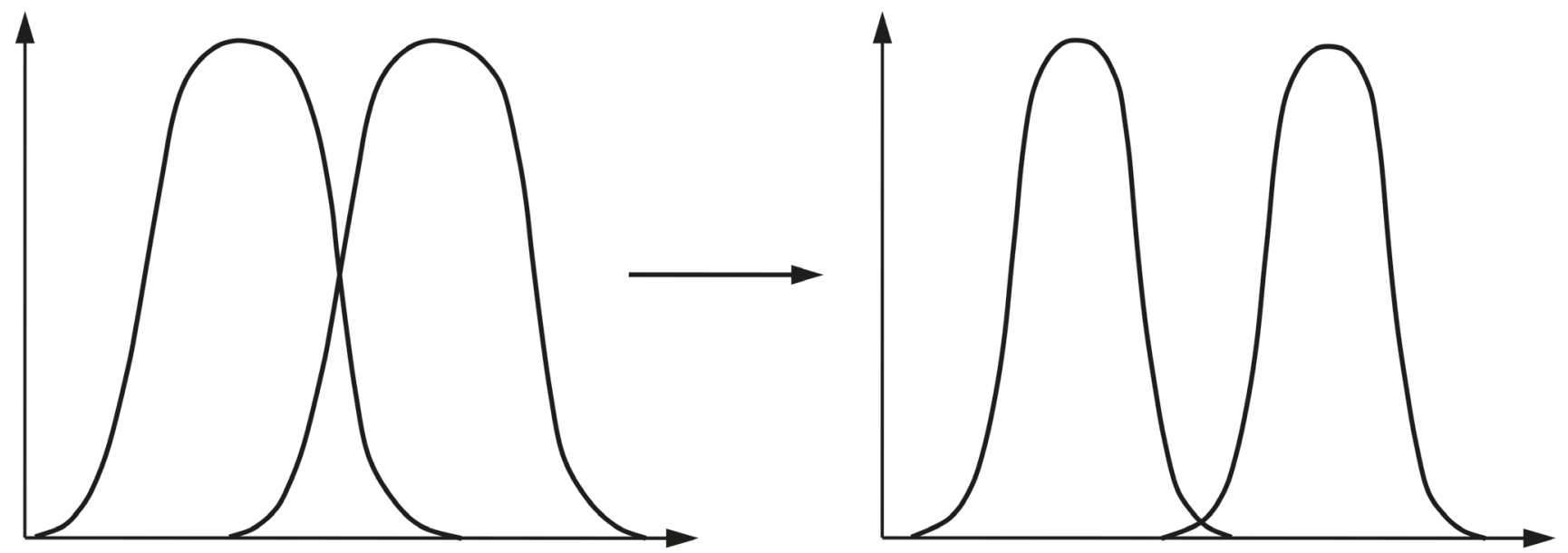

Fig. 1. The evolutionary results of interspecific competition in depending on the degree of species niche overlap: in the case of a large overlap between the niches in the environments with a large range of regular variability in time (A), in the case of a small niche overlap in the relatively stable environments (B)

words, in areas with low seasonal climate, species use the central zones of their ecological niches more intensively than the peripheries, that is, their use of niche spaces should approximate a normal probability density distribution, but with a narrower, in comparison with polar and temperate species, zone of intensive use (Fig. 1B). Specialization in such conditions may be enhanced not just by species transitioning from utilization of a wide array of resources to using only their preferred ones (Evans, Warren, and Gaston, 2005), but also by deepening the species adaptations to any available resources and thus transferring them from the category of secondary or accidental to the category of favoured. Therefore, with decreasing climatic seasonality, the tendency for species to narrow their niches and promote their specialization is quite predictable (Klopfer, 1959; MacArthur, 1972). Indeed, it has been found that tropical species inhabit significantly narrower temperature regimes than temperate ones (Kozak and Wiens, 2007; Hua and Wiens, 2010; Cadena et al., 2011), and allopatric sister species in the tropics show greater climatic specialization than those in the temperate zone (Scriber, 1973; Dyer et al., 2007; Kozak and Wiens, 2007, 2010; Fig. 2). However, it is necessary to note that the return tendency when, for example, plant-pollinator interactions become more specialized with the increase of latitude, is also observed in studies (Ollerton and Cranmer, 2002; Slove and Janz, 2010). These facts may be explained by the progressive impoverishment of the flora moving north. At the same time, generalization of those insect pollinators in rela- 


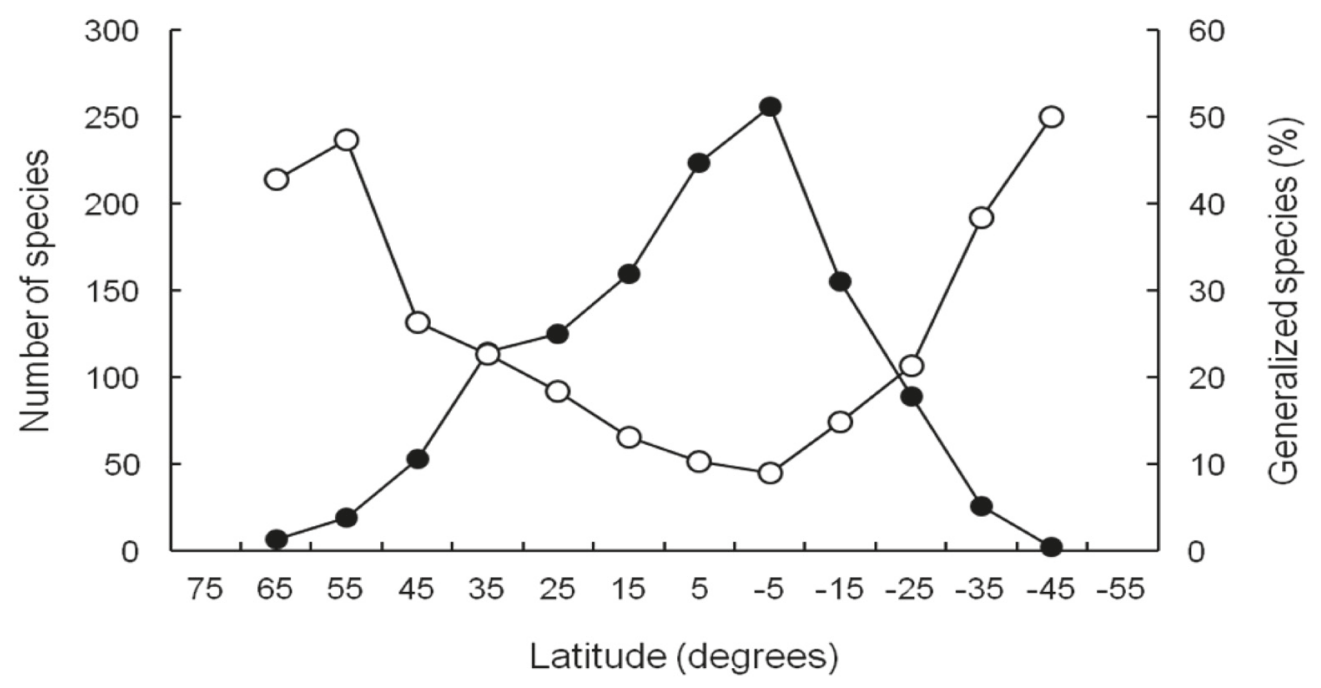

Fig. 2. Latitudinal gradients in species richness (solid circles) and feeding specialization (open circles) of the butterflies of family Papilionidae. The data are pooled by bins of $10^{\circ}$; the value for each latitudinal segment is plotted at the middle of that segment. Negative latitudes are in the southern hemisphere. Modified from Scriber (1973)

tion to many other environmental factors must, to all appearances, be maintained at high latitudes, as it is important to their survival. Thus, the relatively stable (nonseasonal) climate favors segregation and narrowing of species' ecological niches (Fig. 1B), and interspecific interactions, especially competition, that always take place within the biological communities, may additionally intensify this process by means of 'divergence of character' (Darwin, 1872), now termed 'character displacement' (Brown and Wilson, 1956; Hutchinson, 1959).

\section{The degree of niches overlap and the species richness of a region}

Contrary to some authors (e.g., Klopfer and MacArthur, 1961) who believed that species subjected to a narrow range of seasonal climate variability must have more niche overlap and 'less exclusive requirements', we propose that reduced niche-breadths and specialization inevitably generate reduced niche overlapping (Fig. 1B). This is partly supported by the studies of Hua and Wiens (2010). Therefore, the statement that in the tropics there are extremely keen competition and other biotic interactions among the inhabitants (Dobzhansky, 1950; Williams, 1964; Sanders, 1968) also seems not indisputable.

The narrowing of many plant and animal niches and the segregation of them-'species' fidelity to their habitats' or species' 'biotic fidelity' according to Janzen's (1963) terminology - would allow a larger number of species to coexist in a community (Klopfer, 1959), that is, would lead to an increase in species diversity at low latitudes. The reality of the above scenario has been confirmed by a number of field and theoretical studies (Hessler and Sander, 1967; Sanders, 1968; MacArthur,
1975; Angel, 1993; O’Brien, 1993; Archibald, Bossert, Greenwood, and Farell, 2010; Luo et al., 2012). Jungles, tropical coral reefs, the great lakes of tropical Africa and the deep-sea floor, with their very stable environments, are famous for their enormous species diversity. It is interesting to notice that on subtropical mountains, the elevational bands with highest seasonality have fewer species than areas with less seasonality (Wu et al., 2013).

At low latitudes, the narrowing and segregation of ecological niches occurs at the levels of subspecies and populations as well. This is indicated by both the reduced gene flow between tropical populations and their greater isolation by distance (Ogden and Thorpe, 2002; Martin and McKay, 2004), as well as the lesser degree of geographical overlap between the distributions of subspecies of the same species (Rapoport, 1982). This sets up conditions favorable for allopatric and parapatric speciation (Cadena et al., 2011), as a result of which communities in the tropical belt may become quickly saturated with species.

The trend towards decreasing mean geographic range size is also manifested at low latitudes (Stevens, 1989; France, 1992; Letcher and Harvey, 1994; Ruggiero, 1994). However, a direct relationship between the range size of species and their niche breadth may not exist (Ricklefs and Latham, 1992; Williams et al., 2006), and although a relationship between the sizes of species ranges and the species richness of a community has been detected, the strength of this correlation is not strong (Orme et al., 2006). The latter is perfectly understandable: sympatric species may have well-segregated niches and occupy different habitats or microhabitats within the same area. And since the climate and other environmental factors in the tropics are very uniform over 
large areas, many tropical species have rather extensive distributions that are often not smaller than those of high-latitude species (Platnick, 1991; de Oliveira, 1994; Gaston and Chown, 1999; Gardner, 2007). It should be noted that generalization in the tropics is not as impossible as specialization in the polar areas. In the tropical zone, species with broad environmental tolerances often coexist with habitat specialists without reducing richness in jointly occupied habitats (Kolasa, Hewitt, and Drake, 1998).

At high latitudes the situation is different. Various species living there are forced to adapt to a wide range of seasonal variations in the same abiotic and associated biotic variables. As a result, they have not only very wide (Dobzhansky, 1950; Klopfer, 1959), but also widely overlapping ecological niches (Letcher and Harvey, 1994). Grinnell and Storer (1924) came to the conclusion that if two species of the same ecologic predilections are thrown into the same environment, one or the other will quickly disappear through the drastic process which they have called 'competitive replacement'. Since in most cases the high latitude species are not able to avoid interspecific competition or weaken it through competitive divergence - 'divergent character displacement' (Brown and Wilson, 1956; Grant, 1972) - because their environment lacks the habitats or niches where interspecific competition is weak, and into which competing species could retreat and become established, the competition at high latitudes often results in 'competitive exclusion' (Gause, 1934) in the form of competitive extinction (Fig. 1A). The high seasonal and inter-annual environmental variability periodically makes interspecific competition especially keen; Darwin (1872, p.54) considered it the most effective of all checks. Therefore, only a very few, the most robust and adapted species, have been able to survive in such harsh ecosystems, and the species diversity of this zone has undergone a strong reduction (Huston, 1979; Letcher and Harvey, 1994). This is the answer to Hutchinson's (1959, p. 150) question: 'If we can have one or two species of a large family adapted to the rigors of Arctic existence, why can we not have more?'

But because the range of seasonal variations in the most important climatic factors (solar radiation, environmental temperature) decreases on a gradient from the poles to the equator, the species richness of communities increases on a gradient in the same direction. The latitudinal species diversity gradient could be even steeper, but the decline of species diversity in temperate and especially arctic regions is softened by periods of restricted activity by many organisms and the evolution of migration strategies in birds, some mammals and a few insects (Mani, 1968; Ghalambor et al., 2006; Newton, 2008; Hoare, 2009; Jonzen, Knudsen, Holt, and Saether, 2011).
Due to the high degree of generalization, the highlatitude species that survive are able to occupy almost every available habitat, and as a result tend to have large ranges and a considerable number of individuals (Pielou, 1979). In addition, the rigorous selection caused by both harsh abiotic factors and intense biotic interactions could lead to an accelerated adaptive evolution of high-latitude organisms, and could therefore favor the formation of mature equilibrium communities in the polar and midlatitude regions at a rate faster than imagined by some authors (e.g., Fischer, 1960). Recently, it has been shown that the fastest rates of speciation occur in species-poor regions outside the tropics, and that high-latitude fish lineages form new species at much faster rates than their tropical counterparts (Rabosky et al., 2018).

In the upper stratum of the oceans, where seasonal variations, though less pronounced, still hold, the species diversity shows a clear latitudinal gradient (Roy, Jablonski, Valentine, and Rosenberg, 1998; Woodd-Walker, Ward, and Clarke, 2002). Deep-sea environments are relatively well insulated from surface seasonal climatic changes by a thick water cover; therefore, seasonal variations there are generally weak (Nybakken and Bertness, 2004). But such a significant factor as the flux of organic material from the photic zone that changes with seasonal fluctuations in the primary productivity of the surface water shows a quite distinct latitudinal gradient in the amplitude of seasonal variability (Billet, Lampitt, Rice, and Mantoura, 1983). This seems enough to form the latitudinal gradients in species richness of the deep sea that have been detected in some studies (Rex, Stuart, and Coyne, 2000).

Since the southern hemisphere has significantly more ocean and much less land than the northern hemisphere, its climate is more equable and less seasonal at equivalent latitudes, even though it may be humid and less warm (Darwin, 1845/2008; Hartmann, 1994; Gaston and Chown, 1999). Accordingly, peaks of species richness of some taxa in the southern hemisphere are displaced from equatorial ranges to the south, and overall species diversity decreases more slowly towards the South Pole (Darwin, 1845/2008; Platnick, 1991; Eggleton, 1994; Blackburn and Gaston, 1996). In other words, the Earth is 'pear-shaped' in biodiversity (Platnick, 1991).

\section{Factors additionally contributing to increase of species diversity in relatively stable environments}

According to the ideas that have been developed above, the particularly narrow and most segregated niches are most likely to be created by species in those areas where the environment is most stable, or where relatively small amplitude of environmental fluctuations in time is com- 
bined with heterogeneity of physical environment in space. In the second case, the discussion should consider not only topographical heterogeneity, creating physical (Mayr, 1963) or physiological (Janzen, 1967; Fjeldså and Rahbek, 2006; Ghalambor et al., 2006; Kozak and Wiens, 2006) barriers to dispersal of organisms - which are not often insuperable (Chettri, Bhupathy, and Acharya, 2010; Fjeldså et al., 2010) - but first of all should consider spatial heterogeneity of the influence of physiologically important factors that in relatively stable environments may form an evolutionary trend toward increasing specialization and differentiation of groups of organisms, thereby increasing the opportunities for parapatric and allopatric speciation (Cadena et al., 2011), regardless of the organism's ability to overcome certain geographical or physiological obstacles. These processes are accompanied by the narrowing of ecological niches (see previous parts). Increased environmental heterogeneity allows, furthermore, a greater number of species to find the proper conditions for existence (MacArthur and MacArthur, 1961). All this may result in greater species packing within communities.

The combination of a small amplitude of environmental fluctuations in time and heterogeneity of physical environment in space occur, for example, on the slopes of tropical mountains where there are elevational gradients of such factors as temperature, solar radiation, the partial pressure of oxygen and carbon dioxide; or in tropical lakes, rivers and shallow ocean waters where there are depth gradients of decreasing light, temperature, and oxygen concentration; or in the deep sea where the gradients of hydrostatic pressure are ubiquitous. Indeed, many biodiversity and endemism hotspots in the tropics are found in montane regions (Blackburn and Gaston, 1996; Rahbek and Graves, 2001; de Klerk, Crowe, Fjeldså, and Burgess, 2002; Barthlott et al., 2005; Davies et al., 2007), and it is such regions that hold the greatest number of young sister species (Roy, 1997; Hall, 2005). We can expect that the steeper the mountain slope, and hence the greater the rate of environmental changes per unit of slope length (or horizontal distance), the higher the regional species diversity. This is confirmed by field observations. So, in tropical and subtropical mountains the species richness of different organisms - such as various plants, insects, freshwater fishes, amphibians, reptiles, birds, and mammals - along the slopes shows, with very few notable exceptions (Graham, 1990), the characteristic hump-shaped patterns with peaks at some intermediate elevations mostly between 500 and $2000 \mathrm{~m}$ above sea level (Heaney, 2001; Goodman and Rasolonandrasana, 2001; Nor, 2001; Küper et al., 2004; Herzog, Kessler, and Bach, 2005; Oömmen and Shanker, 2005; Smith, de Oca, Reeder, and Wiens, 2007; Li et al., 2009; Chettri, Bhupathy, and Acharya, 2010; Acharya, Sanders, Vijayan, and Chettri, 2011; Larsen, Escobar, and Armbrecht, 2011) - i.e., exactly where the slope is often the steepest and, accordingly, the environmental differentiation is the greatest. Other elevational trends in species richness, such as a high-elevation plateau, a small second hump and so on (Herzog, Kessler, and Bach, 2005; McCain and Grytnes, 2010), might possibly be explained by the specific mountain profiles. Ecological characteristics of taxa (Graham, 1990; Nor, 2001; Goodman and Rasolonandrasana, 2001; Küper et al., 2004; Chettri, Bhupathy, and Acharya, 2010) and regional and local climatic differences (Rahbek, 1995) may also contribute to the shape of the relationship between species richness and altitude. The increase in species richness at intermediate elevations of tropical mountains is accompanied by an increase in the number of range-restricted species (Renjifo et al., 1997; Acharya, Sanders, Vijayan, and Chettri, 2011) and habitat specialists (Acharya, Sanders, Vijayan, and Chettri, 2011).

Upon reaching a certain elevation, the effect of environmental heterogeneity in space on species richness begins to be overlapped by the effect of diurnal environmental variation that can be similar to the effect of annual environmental variability (Sarmiento, 1986; Ghalambor et al., 2006). Along with that, organisms have to expand their physiological tolerance range (Ghalambor et al., 2006) and, in some instances, elevational ranges (McCain, 2009; Chettri, Bhupathy, and Acharya, 2010) - that is, to expand their ecological niches. And the expansion of ecological niches occupied by species and the increase in their overlap should, in turn, lead to increased interspecific competition, followed by extinction of some species and decline of species diversity, as takes place at high latitudes (Fig. 1A). A reduction with elevation of the fitness of environment for a number of taxa (see, e.g., McCain, 2009; Chettri, Bhupathy, and Acharya, 2010) appears to further enhance this effect.

Somewhat earlier (Rex, 1973), hump-shaped diversity patterns, similar to elevational ones, were found in benthic fauna along the depth gradient in the bathyal zone, where the environment is aphotic, there are almost no seasonal temperature variations, and hydrostatic pressure dominates in the determination of physiological barriers to the dispersal of organisms, acting analogously to temperature in the mountain ranges of the terrestrial parts of the world. Later it was found that different benthic organisms such as nematodes, polychaetes, molluscs, crustaceans, echinoderms and fishes show maximum diversity at intermediate depths of 500 to $4000 \mathrm{~m}$, generally between 1000 and $3000 \mathrm{~m}$ (Haedrich, Rowe, and Polloni, 1980; Rex, 1981; Boucher and Lambshead, 1995; Olabarria, 2006). Benthic species are strictly associated with seabed surface and have an environment whose stratification increases directly with an increase in the slope of the seabed, and the slopes between 500 and $4000 \mathrm{~m}$ are confined to the area of the con- 

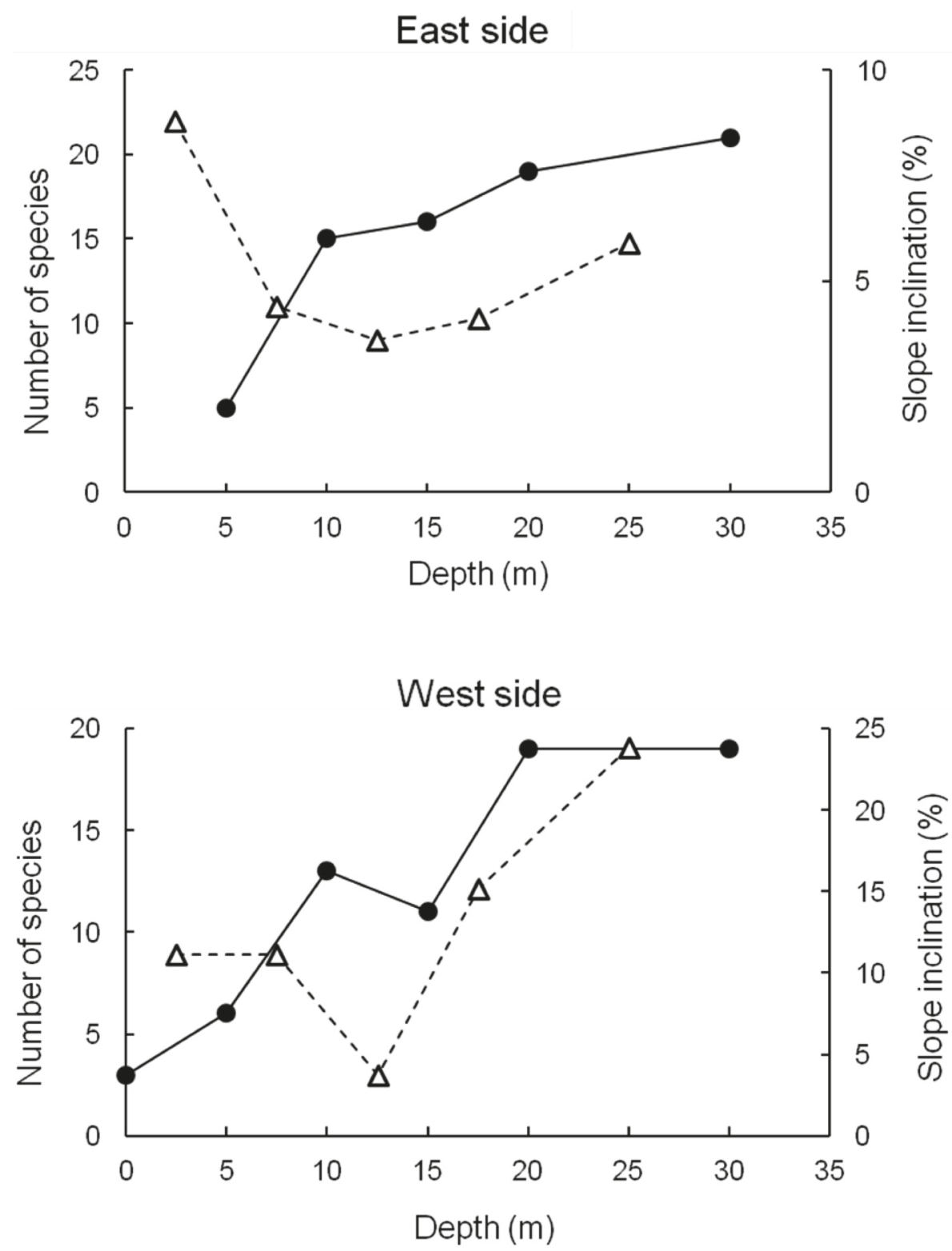

Fig. 3. The relationship between the species richness of all sessile organisms (solid line with circles) on the forereef at Discovery Bay, Jamaica, and the steepness of the reef slopes (dashed line with triangles). Graphs at the top are for the relatively gentle slope of the eastern side of the forereef. Graphs below are for the steeper slope of the western side of the forereef. Modified from Huston (1985b)

tinental margin between the shelf break and the abyssal plain (Menzies, George, and Rowe, 1973) - that is, to the places where the ocean floor has the steepest slopes. Therefore, there is a steep pressure gradient that results in the maximum vertical stratification of the habitat of benthic organisms. Many other environmental factors no doubt have a modifying effect on the deep patterns of species diversity; ecological features of organisms also play important roles in the formation of these patterns. For all of these reasons, different taxa in the same space (Haedrich, Rowe, and Polloni, 1980; Rex, 1981; Olabarria, 2006) and the same taxa in different regions (Stuart, Rex, and Etter, 2003) may reach their peak diversity at different depths. Just like at the middle belt of mountains, an increase in species richness at intermediate depths is accompanied by an increase in the number of endemics and species with narrow and discrete ranges (Jones and Sanders, 1972).

In the relatively stable aquatic environment, peaks in species richness may be a result of not only the increased gradient of hydrostatic pressure, but also the increased gradients of other factors. So, in light-dependent coral communities, the sharp increase of diversity of coral and other sessile organisms from the surface to 5 to $10 \mathrm{~m}$ (Huston, 1985a) may result from overlapping gradients of wave-disturbance and light availability, 
while the highest levels of their diversity that occur in the depth range of 15 to $30 \mathrm{~m}$ (Sheppard, 1980; Huston, $1985 b)$ is largely determined by light availability and the reef profile (Fig. 3).

\section{Conclusion}

Thus, both the latitudinal cline in species diversity and the asymmetry in species richness between the northern and southern hemispheres, along with various species richness patterns along mountain and continental slopes, can be quite plausibly explained by differences in species' adaptive strategies and the different outcomes of interspecific competition in environments with different ranges of regular variability in time and a different degree of spatial differentiation. A relatively stable environment allows species to move more and more towards specialization with a simultaneous narrowing of their ecological niches that in turn leads to a reduction of niche overlap and greater species packing in communities. Interspecific competition and spatial differentiation of an environment may additionally intensify these processes.

In contrast, a wide range of periodic environmental changes in time will cause various species to have not only very large, but also widely overlapping ecological niches. As a result, interspecific competition in such environments tends to be more intense because the environments commonly lack habitats or niches into which competing species could retreat and become established. The outcome of interspecific competition under such conditions inevitably will be competitive extinction (Grinnell and Storer, 1924; Gause, 1934) of many species and a general impoverishment of biota (Huston, 1979; Letcher and Harvey, 1994).

In tropical mountains and on the continental slope, where the environment is stable enough in time, the degree of its differentiation depends mainly on the steepness of slope. And since the steepest slopes tend to be located at intermediate elevations and intermediate bathyal depths, it is there that conditions exist for the highest specialization and closest possible packing of species. This, in combination with increased opportunities for parapatric and allopatric speciation (Cadena et al., 2011), may result in a large amount of coexisting species in these areas - i.e., in the formation of humps of species richness.

These ideas may be referred to as the 'temporal-spatial adaptation theory'. It will hopefully allow us to expand our understanding of the main underlying mechanisms responsible for species richness patterns, prompt researchers to test an association between the elevational and bathymetric diversity patterns and the angle of inclination of the mountain side or the seabed, and provide a framework for new approaches to biodiversity conservation of both different regions and the planet as a whole.

\section{Acknowledgments}

We thank the members of the Department of Biology, Cherepovets State University, for helpful discussion and valuable remarks. We would also like to thank two anonymous reviewers who suggested useful changes, which have allowed us to improve the manuscript substantially.

\section{References}

Acharya, B. K., Sanders, N. J., Vijayan, L., and Chettri, B. 2011. Elevational gradients in bird diversity in the Eastern Himalaya: an evaluation of distribution patterns and their underlying mechanisms. PLOS ONE 6:e29097. https://doi. org/10.1371/journal.pone.0029097

Addo-Bediako, A.S., Chown, S. L., and Gaston, K.J. 2000. Thermal tolerance, climatic variability and latitude. Proceedings of the Royal Society B 267:739-745. https://doi. org/10.1098/rspb.2000.1065

Adler, P. B., Seabloom, E.W., Borer, E. T., Hillebrand, H., ..., and Yang, L. H. 2011. Productivity is a poor predictor of plant species richness. Science 333:1750-1753. https:// doi.org/10.1126/science.1204498

Angel, M. A. 1993. Biodiversity of the pelagic ocean. Conservation Biology 7:760-772. https://doi.org/10.1046/j.15231739.1993.740760.x

Archibald, S. B., Bossert, W. H., Greenwood, D. R., and Farrell, B. D. 2010. Seasonality, the latitudinal gradient of diversity, and Eocene insects. Paleobiology 36:374-398. https://doi.org/10.1016/j.palaeo.2012.10.043

Barthlott, W., Mutke, J., Rafiqpoor, D., Kier, G., and Kreft, H. 2005. Global centers of vascular plant diversity. Nova Acta Leopoldina 92:61-83.

Billet, D. S. M., Lampitt, R. S., Rice, A. L., and Mantoura, R. F. C. 1983. Seasonal sedimentation of phytoplankton to the deep-sea benthos. Nature 302:520-522. https://doi. org/10.1038/302520a0

Blackburn, T. M., Gaston, K.J. 1996. Spatial patterns in the species richness of birds in the New World. Ecography 19:369-376. https://doi.org/10.1111/j.1600-0587.1996. tb00001.x

Boltovskoy, D., Gibbons, M.J., Hutchings, L., and Binet, D. 1999. General biological features of the South Atlantic; pp. 1-42 in Boltovskoy, D. (Ed) South Atlantic zooplankton, Leiden, Backhuys Publishers.

Boucher, G., and Lambshead, P.J.D. 1995. Ecological biodiversity of marine nematodes in samples from temperate, tropical, and deep-sea regions. Conservation Biology 9:1594-1604. https://doi.org/10.1046/j.15231739.1995.09061594.x

Brown, W. L.Jr., and Wilson, E. O. 1956. Character displacement. Systematic Zoology 5:49-64. https://doi. org/10.2307/2411924

Buckley, L. B., and Jetz, W. 2007. Environmental and historical constraints on global patterns of amphibian richness. Proceedings of the Royal Society B 274:1167-1173. https:// doi.org/10.1098/rspb.2006.0436

Bukvareva, E., and Aleshchenko, G. 2013. Optimization, niche and neutral mechanisms in the formation of biodiversity. American Journal of Life Sciences 1(4):174-183. https://doi.org/10.11648/j.ajls.20130104.16

Cadena, C. D., Kozak, K. H., Gómez, J. P., Parra, J. L., ..., and Graham, C. H. 2011. Latitude, elevational climatic zonation and speciation in New World vertebrates. Proceedings of the Royal Society B 279:194-201. https://doi.org/10.1098/ rspb.2011.0720

Chettri, B., Bhupathy, S., and Acharya, B. K. 2010. Distribution pattern of reptiles along an eastern Himalayan elevation 
gradient, India. Acta Oecologica 36:16-22. https://doi. org/10.1016/j.actao.2009.09.004

Clarke, A., and Gaston, K.J. 2006. Climate, energy and diversity. Proceedings of the Royal Society B 273:2257-2266. https://doi.org/10.1098/rspb.2006.3545

Colwell, M. A. 2010. Shorebird ecology, conservation, and management. 344 pp. University of California Press, Berkeley and Los Angeles.

Cousins, S. H. 1989. Species richness and the energy theory. Nature 340:350-351. https://doi.org/10.1038/340350b0

Crame, J. A. 2000. The nature and origin of taxonomic diversity gradients in marine bivalves; pp. 347-360 in: Harper E. M., Taylor J. D., and Crame J. A. (Eds) The evolutionary biology of the Bivalvia. Geological Society of London, Special Publication, 177, London, Alden Press.

Currie, D.J. 1991. Energy and large-scale patterns of animal- and plant-species richness. American Naturalist 137:27-49. https://doi.org/10.1086/285144

Darwin, C. 1845/2008. The Voyage of the Beagle, Cosimo, New York.

Darwin, C. 1872. The Origin of Species by Means of Natural Selection or the Preservation of Favoured Races in the Struggle for Life, 6th edition, John Murray, London.

Davies, R. G., Orme, C. D. L., Storch, D., Olson, V.A., ..., and Gaston, K.J. 2007. Topography, energy and the global distribution of bird species richness. Proceedings of the Royal Society B 274:1189-1197. https://doi.org/10.1098/ rspb.2007.0046

de Klerk, H. M., Crowe, T. M., Fjeldså, J., and Burgess, N. D. 2002. Biogeographical patterns of endemic terrestrial Afrotropical birds. Diversity and Distributions 8:147-162. https://doi.org/10.1046/j.1472-4642.2002.00142.x

de Oliveira, T. G. 1994. Neotropical cats: ecology and conservation. São Luís, Edufma.

Dobzhansky, Th. 1950. Evolution in the tropics. American Scientist 38:209-221.

Dodge, J. D., and Marshall, H. G. 1994. Biogeographic analysis of the armored planktonic dinoflagellate Ceratium in the North Atlantic and adjacent seas. Journal of Phycology 30:905-922. https://doi.org/10.1111/j.00223646.1994.00905.x

Dyer, L. A., Singer, M. S., Lill, J. T., Stireman, J. O., ..., and Coley, P. D. 2007. Host specificity of Lepidoptera in tropical and temperate forests. Nature 448:696-700. https://doi. org/10.1038/nature05884

Eggleton, P. 1994. Termites live in a pear-shaped world: a responsetoPlatnick.JournalofNaturalHistory28:1209-1212. https://doi.org/10.1080/00222939400770611

Emlin, J. M. 1966. The role of time and energy in food preferences. American Naturalist 100:611-617. https://doi. org/10.1086/282455

Evans, K. L., Warren, P. H., Gaston, K. J. 2005. Species-energy relationships at the macroecological scale: a review of the mechanisms. Biological Reviews 80:1-25. https://doi. org/10.1017/S1464793104006517

Fischer,A. G.1960. Latitudinalvariation in organicdiversity. Evolution 14:64-81. https://doi.org/10.1111/j.1558-5646.1960. tb03057.x

Fjeldså, J., and Rahbek, C. 2006. Diversification of tanagers, a species-rich bird group, from the lowlands to montane regions of South America. Integrative and Comparative Biology 46:72-81. https://doi.org/10.1093/icb/icj009

Fjeldså, J., Kiure, J., Doggart, N., Hansen, L. A., and Perkin, A. 2010. Distribution of highland forest birds across a potential dispersal barrier in the Eastern Arc Mountains of Tanzania. Steenstrupia 32:1-43.

Floeter, S. R., and Soares-Gomes, A. 1999. Biogeographic and species richness patterns of Gastropoda on the south- western Atlantic. Revista Brasileira de Biologia 59:567-575. https://doi.org/10.1590/S0034-71081999000400006

France, R. 1992. The North American latitudinal gradient in species richness and geographical range of freshwater crayfish and amphipods. American Naturalist 139:342-354. https://doi.org/10.1086/285330

Fuhrman, J. A., Steele, J. A., Hewson, I., Schwalbach, M. S., ..., and Brown, J. H. 2008. A latitudinal diversity gradient in planktonic marine bacteria. Proceedings of the National Academy of Sciences USA 105:7774-7778. https://doi. org/10.1073/pnas.0803070105

Gardner, A. L. 2007. Mammals of South America. Volume 1: Marsupials, Xenarthrans, Shrews and Bats. University of Chicago Press, Chicago.

Gaston, A. J., and Jones, I. L. 1998. The auks: Alcidae. Oxford University Press, Oxford.

Gaston, K.J., and Chown, S. L. 1999. Why Rapoport's rule does not generalise. Oikos 84:309-312. https://doi. org/10.2307/3546727

Gaston K.J. 2000. Global patterns in biodiversity. Nature 405:220-227. https://doi.org/10.1038/35012228

Gause, G.F. 1934. The Struggle for Existence. Williams and Wilkins, Baltimore.

Ghalambor, C. K., Huey, R. B., Martin, P. R., Tewksbury, J. J., and Wang, G. 2006. Are mountain passes higher in the tropics? Janzen's hypothesis revisited. Integrative and Comparative Biology 46:5-17. https://doi.org/10.1093/icb/icj003

Gillman, L. N., and Wright, S. D. 2006. The influence of productivity on the species richness of plants: a critical assessment. Ecology 87:1234-1243. https://doi. org/10.1890/0012-9658(2006)87[1234:TIOPOT]2.0.CO;2

Goodman, S. M., and Rasolonandrasana, B.P. N. 2001. Elevational zonation of birds, insectivores, rodents and primates on the slopes of the Andringitra Massif, Madagascar. Journal of Natural History 35:285-305. https://doi. org/10.1080/00222930150215387

Graham, G. L. 1990. Bats versus birds: comparisons among Peruvian volant vertebrate faunas along an elevational gradient. Journal of Biogeography 17:657-668. https:// doi.org/10.2307/2845147

Grant, P. R. 1972. Convergent and divergent character displacement. Biological Journal of the Linnean Society 4:3968. https://doi.org/10.1111/j.1095-8312.1972.tb00690.x

Grinnell, J., and Storer, T. I. 1924. Animal Life in the Yosemite. University of California Press, Berkeley.

Haedrich, R. L., Rowe, G. T., and Polloni, P. T. 1980. The megabenthic fauna in the deep sea south of New England, USA. Marine Biology 57:165-179. https://doi.org/10.1007/ BF00390735

Hall, J. P. W. 2005. Montane speciation patterns in Ithomiola butterflies (Lepidoptera: Riodinidae): are they consistently moving up in the world? Proceedings of the Royal Society B 272:2457-2466. https://doi.org/10.1098/ rspb.2005.3254

Hartmann, D. L. 1994. Global physical climatology. Academic Press, San Diego.

Heaney, L. R. 2001. Small mammal diversity along elevational gradients in the Philippines: an assessment of patterns and hypotheses. Global Ecology and Biogeography 10:15-39. https://doi.org/10.1046/j.1466-822x.2001.00227.x

Herzog, S. K., Kessler, M., and Bach, K. 2005. The elevational gradient in Andean bird species richness at the local scale: a foothill peak and a high-elevation plateau. Ecography 28:209-222. https://doi.org/10.1111/j.09067590.2005.03935.x

Hessler, R. R., and Sanders, H. L. 1967. Faunal diversity in the deep-sea. Deep Sea Research and Oceanographic 14:65-78. https://doi.org/10.1016/0011-7471(67)90029-0 
Hoare, B. 2009. Animal migration: remarkable journeys in the wild. University of California Press, Berkeley.

Hua, X., and Wiens, J.J. 2010. Latitudinal variation in speciation mechanisms in frogs. Evolution 64:429-443. https:// doi.org/10.1111/j.1558-5646.2009.00836.x

Huston, M.A. 1979. A general hypothesis of species diversity. American Naturalist 113:81-101. https://doi. org/10.1086/283366

Huston, M. A. 1985a. Patterns of species diversity in relation to depth at Discovery Bay, Jamaica. Bulletin of Marine Science 37:928-935.

Huston, M. A. 1985b. Patterns of species diversity on coral reef. Annual Review of Ecology and Systematics 16:149-177. https://doi.org/10.1146/annurev.es.16.110185.001053

Huston, M. A. 1994. Biological diversity. Cambridge University Press, Cambridge.

Hutchinson, G. E. 1959. Homage to Santa Rosalia, or why are there so many kinds of animals? American Naturalist 93:145-159. https://doi.org/10.1086/282070

Janzen, D. H. 1967. Why mountain passes are higher in the tropics. American Naturalist 101:233-249. https://doi. org/10.1086/282487

Janzen, D. H. 1981. The peak in North American ichneumonid species richness lies between $38^{\circ}$ and $42^{\circ} \mathrm{N}$. Ecology 62:532-537. https://doi.org/10.2307/1937717

Johnsgard, P. A. 1981. The plovers, sandpipers, and snipes of the world, University of Nebraska Press, Lincoln.

Jones, N. S., and Sanders, H. L. 1972. Distribution of Cumacea in the deep Atlantic. Deep Sea Research and Oceanographic Abstracts 19:737-745. https://doi.org/10.1016/00117471(72)90066-6

Jonzen, N., Knudsen, E., Holt, R., Saether, B.-E. 2011. In: Milner-Gulland, E. J., Fryxell, J. M., and Sinclair, A. R. E. (Eds) Animal migration: a synthesis, Oxford, Oxford University Press 91-109.

Kolomiytsev, N.P., and Poddubnaya, N. Ya. 2007. The origin of life as a result of changing the evolutionary mechanism. Rivista di Biologia / Biology Forum 100:11-16.

Klopfer, P. H. 1959. Environmental determinants of faunal diversity. American Naturalist 93:337-342. https://doi. org/10.1086/282092

Klopfer, P. H., and MacArthur, R. 1961. On the causes of tropical species diversity: niche overlap. American Naturalist 95:223-226. https://doi.org/10.1086/282179

Kolasa, J., Hewitt, C. L., and Drake, J. A. 1998. Rapoport's rule: an explanation or a byproduct of the latitudinal gradient in species richness? Biodiversity and Conservation 7:1447-1455. https://doi.org/10.1023/A:1008805230673

Kozak, K. H., and Wiens, J.J. 2006. Does niche conservatism promote speciation? A case study in North American salamanders. Evolution 60:2604-2621. https://doi. org/10.1554/06-334.1

Kozak, K. H., and Wiens, J.J. 2007. Climatic zonation drives latitudinal variation in speciation mechanisms. Proceedings of the Royal Society B 274:2995-3003. https://doi. org/10.1098/rspb.2007.1106

Kozak, K. H., and Wiens, J. J. 2010. Accelerated rates of climatic-niche evolution underlie rapid species diversification. Ecology Letters 13:1378-1389. https://doi.org/10.1111/ j.1461-0248.2010.01530.x

Küper, W., Kreft, H., Nieder, J., Köster, N., and Barthlott, W. 2004. Large-scale diversity patterns of vascular epiphytes in Neotropical montane rain forests. Journal of Biogeography 31:1477-1487. https://doi.org/10.1111/ j.1365-2699.2004.01093.x

Larsen, T.H., Escobar, F., and Armbrecht, I. 2011. Insects of the Tropical Andes: Diversity Patterns, Processes and Global Change; pp. 228-244 in: Herzog, S. K., Mar- tínez, R., Joergensen, P. M., and Tiessen, H. (Eds). Climate change effects on the biodiversity of the tropical Andes: an assessment of the status of scientific knowledge. Brazil and Paris, Inter-American Institute for Global Change Research and Scientific Committee on Problems of the Environment, São José dos Campos.

Letcher, A. J., and Harvey, P. H. 1994. Variation in geographical range size among mammals of the Palearctic. American Naturalist 144:30-42. https://doi.org/10.1086/285659

Levin, L. A. 2003. Oxygen minimum zone benthos: adaptation and community response to hypoxia. Oceanography and Marine Biology: an Annual Review 41:1-45.

Li, J., He, Q., Hua, X., Zhou, J., Xu, H., Chen, J., and Fu, C. 2009. Climate and history explain the species richness peak at mid-elevation for Schizothorax fishes (Cypriniformes: Cyprinidae) distributed in the Tibetan Plateau and its adjacent regions. Global Ecology and Biogeography 18:123-136. https://doi.org/10.1111/j.14668238.2008.00430.x

Lomolino, M. V., Riddle, B. R., Whittaker, R. J. and Brown, J. H. 2010. Biogeography, 4th edition.

Luo, Z., Tang, S., Li, C., Fang, H., Hu, H., Yang, J., Ding, J., and Jiang, Z. 2012. Environmental effects on vertebrate species richness: testing the energy, environmental stability and habitat heterogeneity hypotheses. PLOS ONE 7:e35514. https://doi.org/10.1371/journal.pone.0035514

MacArthur, J.W. 1975 Environmental fluctuations and species diversity; pp. 74-80 in Cody, ML \& Diamond, JM (Eds) Ecology and evolution of communities. Cambridge, Belknap Press.

MacArthur, R. H. 1955. Fluctuations of animal populations and a measure of community stability. Ecology 36:533-536. https://doi.org/10.2307/1929601

MacArthur, R. H. 1972. Geographical ecology: patterns in the distribution of species. Princeton University Press, Princeton.

MacArthur, R. H. and MacArthur, J.W. 1961. On bird species diversity. Ecology 42:594-598. https://doi. org/10.2307/1932254

MacArthur, R. H. and Wilson, E. O. 1967. The theory of island biogeography. Princeton University Press, Princeton.

Macpherson, E. 2002. Large-scale species-richness gradients in the Atlantic Ocean. Proceedings of the Royal Society $B$ 95:3699-3702. https://doi.org/10.1098/rspb.2002.2091

Mani, M.S. 1968. Ecology and biogeography of high altitude insects. Series Entomologica. Vol.4. Dr. W. Junk N. V. Publishers, The Hague.

Martin, P. R. and McKay, J. K. 2004. Latitudinal variation in genetic divergence of populations and the potential for future speciation. Evolution 58:938-945. https://doi. org/10.1111/j.0014-3820.2004.tb00428.x

Martin, P.R. and Tewksbury, J.J. 2008. Latitudinal variation in subspecific diversification of birds. Evolution 62:2775-2788. https://doi.org/10.1111/j.15585646.2008.00489.x

Mayr, E. 1963. Animal species and evolution. Harvard University Press, Cambridge.

McCain, C.M. 2009. Vertebrate range sizes indicate that mountains may be 'higher' in the tropics. Ecology Letters 12:550-560. https://doi.org/10.1111/j.14610248.2009.01308.x

McCain, C. M. and Grytnes, J.-A. 2010. Elevational gradients in species richness; pp. 1-10 in Encyclopedia of Life Sciences (ELS), Chichester, John Wiley and Sons (Ltd). https:// doi.org/10.1002/9780470015902.a0022548

Menzies, R.J., George, R. Y., and Rowe, G.T. 1973. Abyssal environment and ecology of the world oceans. WileyInterscience, New York and London. 
Mittelbach, G. G., Steiner, C. F., Scheiner, S. M., Gross, K. L., ... Gough, L. 2001. What is the observed relationship between species richness and productivity? Ecology 82:2381-2396. https://doi.org/10.1890/00129658(2001)082[2381:WITORB]2.0.CO;2

Mittelbach, G. G., Schemske, D. W., Cornell, H. V., Allen, A. P., ... Turelli, M. 2007. Evolution and the latitudinal diversity gradient: speciation, extinction and biogeography. Ecology Letters 10:315-331. https://doi.org/10.1111/j.14610248.2007.01020.x

Morse, D. H. 1971. The insectivorous bird as an adaptive strategy. Annual Review of Ecology and Systematics 2:177-200. https://doi.org/10.1146/annurev.es.02.110171.001141

Newton, I. 2008. The Migration Ecology of Birds. Academic Press, London.

Nor, S. M. D. 2001. Elevational diversity patterns of small mammals on Mount Kinabalu, Sabah, Malaysia. Global Ecology and Biogeography 10:41-62. https://doi. org/10.1046/j.1466-822x.2001.00231.x

Nybakken, J.W., Bertness, M.D. 2004. Marine Biology: An Ecological Approach. 6th ed, Benjamin Cummings, San Francisco.

O'Brien, E. M. 1993. Climatic gradients in woody plant species richness: towards an explanation based on an analysis of southern Africa's woody flora. Journal of Biogeography 20:181-198. https://doi.org/10.2307/2845670

Ogden, R. and Thorpe, R. S. 2002. Molecular evidence for ecological speciation in tropical habitats. Proceedings of the National Academy of Sciences USA 99:13612-13615. https://doi.org/10.1073/pnas.212248499

Olabarria, C. 2006. Faunal change and bathymetric diversity gradient in deep-sea prosobranchs from Northeastern Atlantic. Biodiversity and Conservation 15:3685-3702. https://doi.org/10.1007/s10531-005-1344-9

Ollerton, J. and Cranmer, L. 2002. Latitudinal trends in plantpollinator interactions: Are tropical plants more specialized? Oikos 98:340-350. https://doi.org/10.1034/j.16000706.2002.980215.x

Oömmen, M.A. and Shanker, K. 2005. Elevational species richness patterns emerge from multiple local scale mechanisms in Himalayan plants. Ecology 86:3039-3047. https://doi.org/10.1890/04-1837

Orme, C.D., Davies, R. G., Olson, V.A., ..., and Gaston, K. J. 2006. Global patterns of geographic range size in birds. PLoS Biology 4:e208. https://doi.org/10.1371/journal. pbio.0040208

Owen, R. W. 1981. Fronts and eddies in the sea: mechanisms, interactions and biological effects; pp. 197-233 in: Longhurst, AR (Ed) Analysis of marine ecosystems. London, Academic Press.

Pärtel, M., Laanisto, L., and Zobel, M. 2007. Contrasting plant productivity-diversity relationships across latitude: the role of evolutionary history. Ecology 88:1091-1097. https://doi.org/10.1890/06-0997

Peck, S. B. and Kaulbars, M. M. 1987. A synopsis of the distribution of the carrion beetles (Coleoptera: Silphidae) of the conterminous United States. Proceedings of the Entomological Society of Ontario 188:47-81.

Pianka, E. R. 1966. Latitudinal gradients in species diversity: a review of the concepts. American Naturalist 100:33-46. https://doi.org/10.1086/282398

Pianka, E. R. 1970. On r- and K-selection. American Naturalist 104:592-597. https://doi.org/10.1086/282697

Pielou, E.C. 1979. Biogeography. Wiley Interscience, New York.

Platnick, N. I. 1991. Patterns of biodiversity: tropical vs temperate. Journal of Natural History 25:1083-1088. https:// doi.org/10.1080/00222939100770701
Powney, G. D., Grenyer, R., Orme, C. D. L., Owens, I. P. F., and Meiri, S. 2010. Hot, dry and different: Australian lizard richness is unlike that of mammals, amphibians and birds. Global Ecology and Biogeography 19:386-396. https://doi.org/10.1111/j.1466-8238.2009.00521.x

Pringle, C. M. 2000. River conservation in Latin America and the Caribbean; pp. 371-384 in Boon, PJ, Davies, BR \& Petts, GE (Eds) Global Perspectives on River Conservation: Science, Policy and Practice. Chichester, John Wiley and Sons.

Pyron, R. A. and Burbrink, F. T. 2009. Can the tropical conservatism hypothesis explain temperate species richness patterns? An inverse latitudinal biodiversity gradient in the New World snake tribe Lampropeltini. Global Ecology and Biogeography 18:406-415. https://doi.org/10.1111/ j.1466-8238.2009.00462.x

Rabosky, D. L., Chang, J., Title, P. O., Cowman, P. F., Sallan, L., Friedman, M., Kaschner, K., Garilao, C., Near, Th. J., Coll, M., and Alfaro, M. E. 2018. An inverse latitudinal gradient in speciation rate for marine fishes. Nature 559:392395. https://doi.org/10.1038/s41586-018-0273-1

Rahbek, C. 1995. The elevational gradient of species richness: a uniform pattern? Ecography 18:200-205. https://doi. org/10.1111/j.1600-0587.1995.tb00341.x

Rahbek, C. and Graves, G. R. 2001. Multiscale assessment of patterns of avian species richness. Proceedings of the National Academy of Sciences USA 98:4534-4539. https:// doi.org/10.1073/pnas.071034898

Rapoport, E. H. 1982. Areography: Geographical Strategies of Species, Pergamon Press, Oxford.

Renjifo, L. M., Servat, G.P., Goerck, J. M., Loiselle, B. A., and Blake, J. G. 1997. Patterns of species composition and endemism in the northern Neotropics: a case for conservation of montane avifaunas. Ornithological Monographs 48:577-594. https://doi.org/10.2307/40157554

Rex, M. A. 1973. Deep-sea species diversity: decreased gastropod diversity at abyssal depths. Science 181:1051-1053. https://doi.org/10.1126/science.181.4104.1051

Rex, M. A. 1981. Community structure in the deep-sea benthos. Annual Review of Ecology and Systematics 12:331-353. https://doi.org/10.1146/annurev.es.12.110181.001555

Rex, M. A. and Etter, R. J. 2010. Deep-Sea Biodiversity: Pattern and Scale. Harvard University Press, Cambridge.

Rex, M. A., Stuart, C. T., and Coyne, G. 2000. Latitudinal gradients of species richness in the deep-sea benthos of the North Atlantic. Proceedings of the National Academy of Sciences USA 97:4082-4085. https://doi.org/10.1073/ pnas.050589497

Ricklefs, R. E. and Latham, R. E. 1992. Intercontinental correlation of geographical ranges suggests stasis in ecological traits of relict genera of temperate perennial herbs. American Naturalist 139:1305-1321. https://doi. org/10.1086/285388

Rosenzweig, M. L. 1995. Species diversity in space and time, Cambridge University Press, Cambridge.

Roy, M.S. 1997. Recent diversification of African greenbuls (Pycnonotidae: Andropadus) supports a montane speciation model. Proceedings of the Royal Society $B$ 264:1337-1344. https://doi.org/10.1098/rspb.1997.0185

Roy, K., Jablonski, D., Valentine, J. W., and Rosenberg, G. 1998. Marine latitudinal diversity gradients: tests of causal hypotheses. Proceedings of the National Academy of Sciences USA 95:3699-3702. https://doi.org/10.1073/ pnas.95.7.3699

Ruggiero, A. 1994. Latitudinal correlates of the sizes of mammalian geographical ranges in South America. Journal of Biogeography 21:545-559. https://doi. org/10.2307/2845657 
Rutherford, S., D'Hondt, S., and Prell, W. 1999. Environmental controls on the geographic distribution of zooplankton diversity. Nature 400:749-753. https://doi. org/10.1038/23449

Sanders, H. L. 1968. Marine benthic diversity: a comparative study. American Naturalist 102:243-282. https://doi. org/10.1086/282541

Sarmiento, G. 1986. Ecologically crucial features of climate in high tropical mountains; pp. 11-46 in Vuilleumier, F. and Monasterio, M. (Eds). High altitude tropical biogeography. New York, Oxford University Press.

Schmalhausen, I. I. 1949. Factors of Evolution: The Theory of Stabilizing Selection. Blakiston, Philadelphia.

Schmit, J. P. 2005. Species richness of tropical wood-inhabiting macrofungi provides support for species-energy theory. Mycologia 97:751-761. https://doi.org/10.1080/1 5572536.2006.11832766

Scriber, J. M. 1973. Latitudinal gradients in larval feeding specialization of the world Papilionidae (Lepidoptera). Psyche 80:355-373. https://doi.org/10.1155/1973/52610

Sheppard, C. R. C. 1980. Coral cover, zonation and diversity on reef slopes of Chagos Atolls, and population structures of the major species. Marine Ecology - Progress Series 2:193-205. https://doi.org/10.3354/meps002193

Slansky, F. 1972. Latitudinal gradients in species diversity of the New World swallowtail butterflies. Journal of Research on the Lepidoptera 11:201-218.

Slobodkin, L. B. and Sanders, H. L. 1969. On the contribution of environmental predictability to species diversity. Brookhaven Symposium in Biology 22:82-95.

Slove, J. and Janz, N. 2010. Phylogenetic analysis of the latitude-niche breadth hypothesis in the butterfly subfamily Nymphalinae. Ecological Entomology 35:768-774. https:// doi.org/10.1111/j.1365-2311.2010.01238.x

Smith, S. A., de Oca, A. N. M., Reeder, T.W., and Wiens, T.W. 2007. A phylogenetic perspective on elevational species richness patterns in Middle American treefrogs: why so few species in lowland tropical rainforests? Evolution 61:1188-1207. https://doi.org/10.1111/j.15585646.2007.00085.x

Stevens, G. C. 1989. The latitudinal gradient in geographical range: how so many species coexist in the tropics. American Naturalist 133:240-256. https://doi. org/10.1086/284913

Stuart, C. T., Rex, M. A., and Etter, R. J. 2003. Large-scale spatial and temporal patterns of deap-sea benthic species diversity; pp. 297-313 in Tyler, P. A. (Ed) Ecosystems of the world. Volume 28. Ecosystems of the deep oceans. Amsterdam, Elsevier.

Turner, J. R. G., Gatehouse, C. M., and Corey, C. A. 1987. Does solar energy control organic diversity? Butterflies, moths and the British climate. Oikos 48:195-205. https://doi. org/10.2307/3565855

Väinölä, R., Witt, J. D. S., Grabowski, M., Bradbury, J. H., Jazdzewski, K., and Sket, B. 2008. Global diversity of am- phipods (Amphipoda; Crustacea) in freshwater. Hydrobiologia 595:241-255. https://doi.org/10.1007/s10750007-9020-6

Valdovinos, C., Navarette, S. A., and Marquet, P. A. 2003. Mollusk species diversity in the Southeastern Pacific: why are there more species towards the pole? Ecography 26:139-144. https://doi.org/10.1034/j.16000587.2003.03349.x

Veron, J. E. N. 1995. Corals in space and time: The biogeography and evolution of the scleractinia. University of the New South Wales Press, New South Wales, Sydney.

von Humboldt, A. 1808. Ansichten der Natur: mit wissenschaftlichen Erläuterungen. J. G. Cotta'schen Buchhandlung, Tübingen.

Wallace, A. R. 1878. Tropical nature and other essays. Macmillan, New York.

Wiens, J.J. 2007. Global patterns of species richness and diversification in amphibians. American Naturalist 170:86-106. https://doi.org/10.1086/519396

Williams, C. B. 1964. Patterns in the balance of nature: and related problems in quantitative ecology. Academic Press, New York.

Williams, T. D. 1995. The penguins: Spheniscidae. Oxford University Press, Oxford.

Williams, Y. M., Williams, S. E., Alford, R. A., Waycott, M., and Johnson, C. N. 2006. Niche breadth and geographical range: ecological compensation for geographical rarity in rainforest frogs. Biology Letters 2:532-535. https://doi. org/10.1098/rsbl.2006.0541

Willig, M. R., Kaufman, D. M., and Stevens, R. D. 2003. Latitudinal gradients of biodiversity: pattern, process, scale, and synthesis. Annual Review of Ecology, Evolution, and Systematics 34:273-309. https://doi.org/10.1146/annurev. ecolsys.34.012103.144032

Wilson, D. E, and Reeder, D. M. (Eds) 2005. Mammal Species of the World: A Taxonomic and Geographic Reference, 3rd ed, Baltimor, Johns Hopkins University Press.

Woodd-Walker, R. S., Ward, P., and Clarke, A. 2002. Large scale patterns in diversity and community structure of surface water copepods from the Atlantic Ocean. Marine Ecology Progress Series 236:189-203. https://doi.org/10.3354/ meps236189

Wright, D. H., Currie, D. J., and Maurer, B. A. 1993. Energy supply and patterns of species richness on local and regional scales; pp. 66-74 in Ricklefs, R. E. and Schluter D. (Eds) Species Diversity in Ecological Communities. Chicago, University of Chicago Press.

Wright, S. J. 2002. Plant diversity in tropical forests: a review of mechanisms of species coexistence. Oecologia 130:1-14. https://doi.org/10.1007/s004420100809

Wu, Y., Colwell, R. K., Rahbek, C., Zhang, C., Quan, Q., Wang, C., and Le, L. 2013. Explaining the species richness of birds along a subtropical elevational gradient in the Hengduan Mountains. Journal of Biogeography 40:2310-2323. https://doi.org/10.1111/jbi.12177 